\title{
Tartaric Acid Grafted Sugarcane Bagasse for Removal of Chromium(VI) from Aqueous Solutions
}

\author{
Adel M. Kamal El-Dean ${ }^{1}$, Mostafa M. Ahmed², Sawsan M. \\ Hussain $^{3}$ and Elham Y. Hashem ${ }^{1 *}$ \\ ${ }^{I}$ Department of Chemistry, Faculty of Science, Assuit University, \\ Assuit, Egypt \\ ${ }^{2}$ Department of Chemistry, Faculty of Science, New Valley University, \\ Egypt \\ ${ }^{3}$ Faculty of Sugar and Integrated Industries Technology, Assiut \\ University, Egypt
}

*Corresponding Author: Tel: +201000005313, Fax: +20882080209

\begin{abstract}
Hexavalent chromium is a priority toxic and carcinogenic chemical when present in excess. It is very much required to remove it from effluents before allowing it to enter any water system or on to land. In the present study, the removal of $\mathrm{Cr}(\mathrm{VI})$ by adsorptionfrom wastewater using low cost adsorbent modified sugarcane bagasse by tartaric acid (SCB) was studied. The effect of the initial concentration of $\mathrm{Cr}(\mathrm{VI})$, bio sorbent dosage, temperature, contact time, and $\mathrm{pH}$ were studied. It was noted that the removal decreased with the increase in the initial concentration of $\mathrm{Cr}(\mathrm{VI})$ ions and also $\mathrm{pH}$. The adsorption of $\mathrm{Cr}(\mathrm{VI})$ from water was favorable at low $\mathrm{pH}$ values. The kinetic of the $\mathrm{Cr}(\mathrm{VI})$ adsorption on SCB was found to follow pseudo - second order mechanism. The adsorption data can be satisfactorily explained by Freundlich isotherm. This work proved that treated bagasse can be used as an efficient adsorbent material for removal of $\mathrm{Cr}(\mathrm{VI})$ from wastewater.
\end{abstract}

Keywords: Adsorption; Sugarcane bagasse; Hexavalent chromium; Tartaric acid.

\section{Introduction}

The contamination of water and Environment are discharged by a number of industries, such as metal platingfacilities, mining operations and tanneries. ${ }^{1}$ These metals are significantly toxic to 
human beings and ecological environments. ${ }^{2}$ A serious health hazard result from dissolved heavy metals escaping into the environment which accumulate throughout the food chain in living tissues, multiplying their effects so it is necessary to eliminate them to protect public health ${ }^{3}$. Among various treatment technologies for purification of wastewaters from heavy metals, adsorption was found to be the most commonly used method for eliminating these contaminants, especially at low concentrations.

Different adsorbents have been developed from available natural materials such as activated carbon, pine bark, charcoal, banana peel, tar sands, modified rice husk, zeolites and moss peat. ${ }^{4-8}$ Sugarcane bagasse was widely used to remove heavy metals. ${ }^{9-10}$ Sugarcane bagasse has around $50 \%$ cellulose, $27 \%$ polyoses, and $23 \%$ lignin, ${ }^{11}$ which have many hydroxyl and/or phenolic functions that can chemically react to produce materials with new properties. ${ }^{12}$ Only a few among these works investigated the modification of sugarcane bagasse.

The maximum of $\mathrm{Cr}(\mathrm{VI})$ levels permitted in wastewater are $5 \mathrm{mg}$ $\mathrm{L}^{-1}$ for trivalent chromium and $0.05 \mathrm{mg} \mathrm{L}^{-1}$ for hexavalent chromium. ${ }^{13}$ Chromium ions are usually eliminated by precipitation, ion-exchange and adsorption. ${ }^{14-16}$ Many researches for making efficient, eco- friendly, and inexpensive adsorbents are intensivelydeveloped. ${ }^{17}$

The biosorption has some advantages over other techniques, ${ }^{18}$ for example, low cost agricultural waste biproducts such as sugarcane bagasse can be used as adsorbent. ${ }^{19}$ The main objective of this work is to study the adsorption of hexavalent chromium by low cost adsorbent modified SCB with tartaric acid.

\section{Experimental}

\subsection{Materials and Methods}

Aqueous stock solution of $500 \mathrm{ppm}$ of $\mathrm{Cr}(\mathrm{VI})$ was prepared from potassium dichromate using double distilled water by carefully weighting out $0.05 \mathrm{~g}$ of it and dissolved in a $100 \mathrm{ml}$ distilled water. Tartaric acid solution was prepared by dissolution of solid anhydrous acid in the appropriate amount of distilled water. 
The $\mathrm{pH}$ values were adjusted by using sodium hydroxide or hydrochloric acid.

\subsection{Preparation of sugarcane bagasse}

Sugarcane bagasse (SCB) was collected and washed several times using bi-distilled waters to eliminate dust, impurities and other unwanted chemicals. Bagasse was dried at $105{ }^{\circ} \mathrm{C}$ for $48 \mathrm{~h}$ and powdered in an agate mortar and then sieved through a nylon sieve (hole diameter is $0.710 \mathrm{~mm}$ ) to obtain the size fractions for samples.

\subsection{Treatment of SCB by tartaric acid}

Chemical modification of SCB by tartaric acid was performed by mixing the biomass with 6 or $12 \mathrm{~g}$ of tartaric acid dissolved in $300 \mathrm{ml}$ of water for $30 \mathrm{~g} \mathrm{SCB}$. The modified powders were dried at $100{ }^{\circ} \mathrm{C}$ overnight. This modification stabilizes the biomass due to the formation of ester. ${ }^{19}$

\subsection{Calculation of metal ions uptake}

The amount of $\mathrm{Cr}(\mathrm{VI})$ adsorbed onto SCB at equilibrium $\mathrm{q}_{\mathrm{e}} \mathrm{mg}$ $\mathrm{g}^{-1}$ was calculated by:

$$
\mathrm{q}_{\mathrm{e}}=\mathrm{V}\left(\mathrm{C}_{\mathrm{o}}-\mathrm{C}_{\mathrm{e}}\right) / \mathrm{W}
$$

Where $\mathrm{V}(\mathrm{L})$ is the volume of the $\mathrm{Cr}(\mathrm{VI})$ solution and $\mathrm{W}(\mathrm{g})$ is the dry of $\mathrm{SCB}, \mathrm{C}_{\mathrm{o}}$ and $\mathrm{C}_{\mathrm{e}}\left(\mathrm{mg} \mathrm{L}^{-1}\right)$ are initial and equilibrium metal concentrations, respectively. The removal efficiency of the $\mathrm{Cr}(\mathrm{VI})$ was also by the following equation:

$$
\text { R.E } \%=\left(\mathrm{C}_{\mathrm{o}}-\mathrm{C}_{\mathrm{e}}\right) / \mathrm{C}_{\mathrm{o}} * 100
$$

\subsection{Adsorption isotherms}

The distribution of $\mathrm{Cr}(\mathrm{VI})$ between the liquid and the solid phases was described by Langmuir and Freundlich isotherm model using the following equations ${ }^{20-21}$, respectively.

$$
\begin{aligned}
\mathrm{C}_{\mathrm{e}} / \mathrm{q}_{\mathrm{e}} & =1 /\left(\mathrm{q}_{\mathrm{m}^{*}} \mathrm{~b}\right)+\mathrm{C}_{\mathrm{e}} / \mathrm{q}_{\mathrm{m}} \\
\log \mathrm{q}_{\mathrm{e}} & =\log \mathrm{k}_{\mathrm{f}}+1 / \mathrm{n} \log \mathrm{C}_{\mathrm{e}} \quad(\text { linear })
\end{aligned}
$$


Where $\mathrm{q}_{\mathrm{e}}\left(\mathrm{mg} \mathrm{g}^{-1}\right)$ and $\mathrm{C}_{\mathrm{e}}\left(\mathrm{mg} \mathrm{L}^{-1}\right)$ are the amount of metal ion per unit weight of adsorbent and unadsorbed metal ion in solution at equilibrium, respectively, $\mathrm{q}_{\mathrm{m}}\left(\mathrm{mg} \mathrm{g}^{-1}\right)$ is maximum amount of sorbate per unit mass of sorbent when all sites are occupied. $b\left(\mathrm{~L} \mathrm{mg}^{-1}\right)$ is a constant related to the affinity of the binding sites. The separation factor $\left(R_{\mathrm{L}}\right)^{22}$, is used to describe the essential characteristics of Langmuir isotherm, it is defined by

$$
\mathrm{R}_{\mathrm{L}}=1 /\left(1+\mathrm{k} \mathrm{C}_{\mathrm{o}}\right)
$$

\section{Results and Discussion}

\subsection{Adsorption of $\mathrm{Cr}(\mathrm{VI})$ onto tartaric acid modified SCB}

Adsorption of $\mathrm{Cr}$ (VI) from aqueous solution on biosorbents like tartaric acid modified SCB is affected by several factors like $\mathrm{pH}$, dose, initial concentration, contact time and temperature. Most adsorbents interact with $\mathrm{Cr}(\mathrm{VI})$ through binding of the metal ion on the cellulose / lignin units in the active sites through binding of two hydroxyl groups in the cellulose units.

\subsubsection{Effect of initial $\operatorname{Cr}(\mathrm{VI})$ concentration on its bio sorption by SCB}

The effect of initial metal ions concentration on the bio sorption of Cr (VI) by SCB was studied. $20 \mathrm{ml}$ of different initial concentrations $(10,20,40,80,100,150$ and $200 \mathrm{ppm})$ of $\mathrm{Cr}(\mathrm{VI})$ was added to $0.2 \mathrm{~g}$ of SCB modified with $2 \%$ or $4 \%$ tartaric acid at $25^{\circ} \mathrm{C}$, at $\mathrm{pH} 1.5$ and the mixture was stirred at $300 \mathrm{rpm}$ for $15 \mathrm{~min}$. Then the absorbance was recorded at wavelength of $365 \mathrm{~nm}$. The maximum bio sorption capacity $q_{\mathrm{e}}$ of $\mathrm{Cr}(\mathrm{VI})$ ions by SCB modified with $2 \%$ or $4 \%$ tartaric acid was proved to be 9.04 and $11.6 \mathrm{mg} \mathrm{g}^{-1}$ at $200 \mathrm{ppm}$ initial metal ion concentrations, as shown in Figure 1 and Tables 1,2. This showed that the amount of metal ions adsorbed $\left(q_{\mathrm{e}}\right)$ increases as the initial $\mathrm{Cr}$ (VI) concentration rises and the removal efficiency decreases as the initial metal ion concentration increases. Evidently such a behaviour can be attributed to the maintenance of fixed number of binding sites in the fixed adsorbent dosage while increasing the concentration. 
Table 1. Effect of initial $\mathrm{Cr}(\mathrm{VI})$ concentration on the $\mathrm{Cr}(\mathrm{VI})$ removal efficiency and $q_{e}\left(\mathrm{mg} \mathrm{g}^{-1}\right)$ by modified SCB with $2 \%$ tartaric acid.

\begin{tabular}{|c|c|c|c|}
\hline Conc. (ppm) & $\mathbf{C}_{\mathbf{e}}$ & R.E\% & $\mathbf{q}_{\mathbf{e}}$ \\
\hline 20 & 1.75 & 91.23 & 1.83 \\
\hline 40 & 8.79 & 78.03 & 3.12 \\
\hline 60 & 19.81 & 66.99 & 4.02 \\
\hline 100 & 39.30 & 60.70 & 6.07 \\
\hline 140 & 67.26 & 51.96 & 7.27 \\
\hline 180 & 101.16 & 43.80 & 7.88 \\
\hline 200 & 109.64 & 45.18 & 9.04 \\
\hline
\end{tabular}

Table 2. Effect of initial $\mathrm{Cr}(\mathrm{VI})$ concentration on the $\mathrm{Cr}(\mathrm{VI})$ removal efficiency and $q_{e}\left(\mathrm{mg} \mathrm{g}^{-1}\right)$ by modified SCB with $4 \%$ tartaric acid.

\begin{tabular}{|c|c|c|c|}
\hline Conc. (ppm) & $\mathbf{C}_{\mathbf{e}}$ & R.E\% & $\mathbf{q}_{\mathbf{e}}$ \\
\hline 20 & $\mathbf{0 . 4 8}$ & $\mathbf{9 7 . 5 8}$ & $\mathbf{1 . 9 5}$ \\
\hline 40 & $\mathbf{2 . 0 1}$ & $\mathbf{9 4 . 9 8}$ & $\mathbf{3 . 8 0}$ \\
\hline 60 & $\mathbf{8 . 7 9}$ & $\mathbf{8 5 . 3 5}$ & $\mathbf{5 . 1 2}$ \\
\hline 100 & $\mathbf{2 0 . 6 5}$ & $\mathbf{7 9 . 3 5}$ & $\mathbf{7 . 9 5}$ \\
\hline 140 & $\mathbf{5 0 . 3 1}$ & $\mathbf{6 4 . 0 6}$ & $\mathbf{8 . 9 7}$ \\
\hline 180 & $\mathbf{7 5 . 7 4}$ & $\mathbf{5 7 . 9 2}$ & $\mathbf{1 0 . 4 3}$ \\
\hline 200 & $\mathbf{8 4 . 2 1}$ & $\mathbf{5 7 . 8 9}$ & $\mathbf{1 1 . 5 8}$ \\
\hline
\end{tabular}

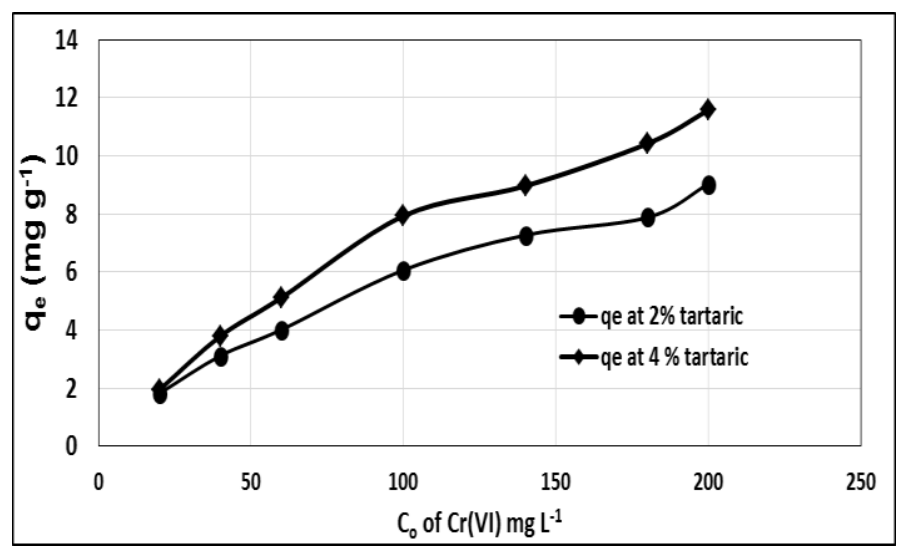

Figure 1. Effect of initial $\mathrm{Cr}(\mathrm{VI})$ concentration on $\mathrm{q}_{\mathrm{e}}\left(\mathrm{mg} \mathrm{g}^{-1}\right)$ by modified SCB with $2 \%$ or $4 \%$ tartaric acid. 


\subsubsection{Effect of $\mathrm{pH}$ on the bio sorption of $\mathrm{Cr}(\mathrm{VI})$ by $\mathrm{SCB}$}

The $\mathrm{pH}$ value is an important factor for controlling the process of adsorption as it affects the surface charge of the adsorbents, the degree of ionization and the species of the adsorb ate. Bio sorption experiments were carried out at different initial $\mathrm{pH}$ values (1-11). 20 $\mathrm{ml}$ of $\mathrm{Cr}(\mathrm{VI})$ solutions of initial concentration of $80 \mathrm{ppm}$ was added to $0.2 \mathrm{~g}$ of modified $\mathrm{SCB}$ at $25^{\circ} \mathrm{C}$ and the mixture was stirred at $300 \mathrm{rpm}$ for $15 \mathrm{~min}$. We observed the highest absorbance at low $\mathrm{pH}$ 1.5 and it decreases as $\mathrm{pH}$ increases. The amount of $\mathrm{Cr}(\mathrm{VI})$ removed by SCB modified by $2 \%$ tartaric acid was $\left(7.2 \mathrm{mg} \mathrm{g}^{-1}\right)$ and removal efficiency $90.1 \%,\left(7.6 \mathrm{mg} \mathrm{g}^{-1}\right.$ and $95.2 \%$ in the case of SCB modified by $4 \%$ tartaric acid). This means that there is strong interaction between the metal ions and the biosorbent in the acidic solution,as shown in Figure 2. The principal driving force for metal ion adsorption is the electrostatic interaction, i.e. attraction between adsorbent and adsorbate. The greater the interaction, the higher the adsorption of heavy metal was found.

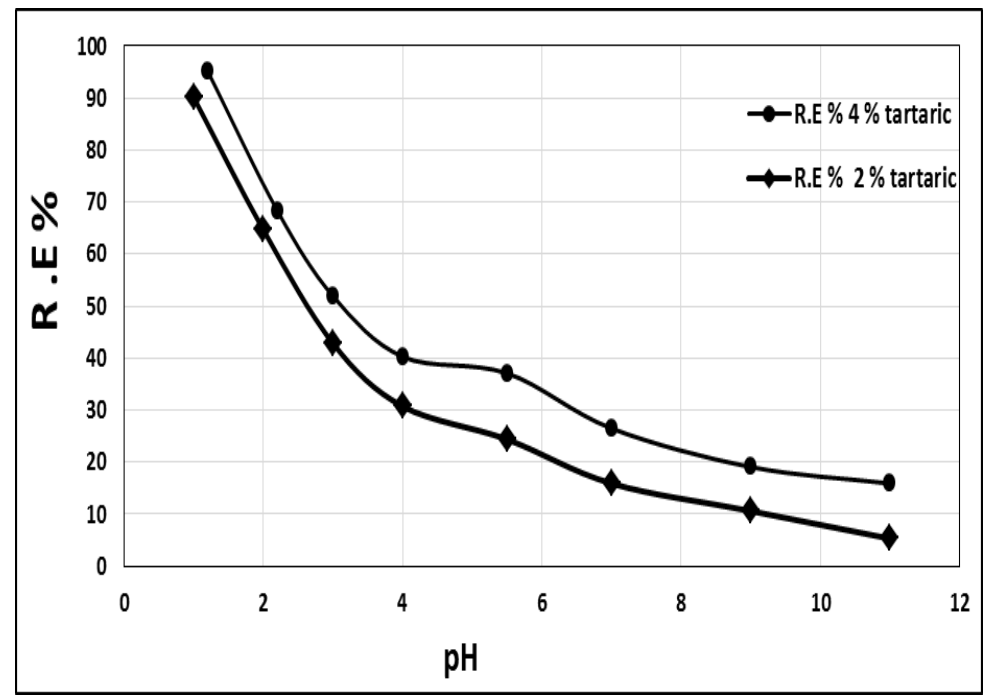

Figure 2. Effect of pH on the $\mathrm{Cr}(\mathrm{VI})$ removal efficiency at initial concentration of $\operatorname{Cr}(\mathrm{VI})(80 \mathrm{ppm})$ by modified SCB with $2 \%$ or $4 \%$ tartaric acid. 


\subsubsection{Effect of bio sorbent dosage on the bio sorption of the $\mathrm{Cr}$} (VI)

The effect of adsorbent mass on the mass adsorption ofCr(VI) was investigated at intial metal ion concentration $80 \mathrm{ppm}$. In each bio sorption experiment, $20 \mathrm{~mL}$ of $\mathrm{Cr}(\mathrm{VI})$ solution of initial concentration (80 ppm ) was added to different dosage of modified SCB biosorbent with $2 \%$ or $4 \%$ tartaric acid at $25^{\circ} \mathrm{C}$, at pH 1.5 and the mixtures were stirred at $300 \mathrm{rpm}$ for $15 \mathrm{~min}$.It was observed that the increase in the biosorbent dosage makes the $\mathrm{Cr}(\mathrm{VI})$ removal efficiency increases as shown in Figure 3.This is due to the increase in surface area and availability of biosorption sites, but the amount adsorbed by unit mass, decreases. This is due to unsaturation of adsorption sites and particle interaction which will decrease the total surface area.

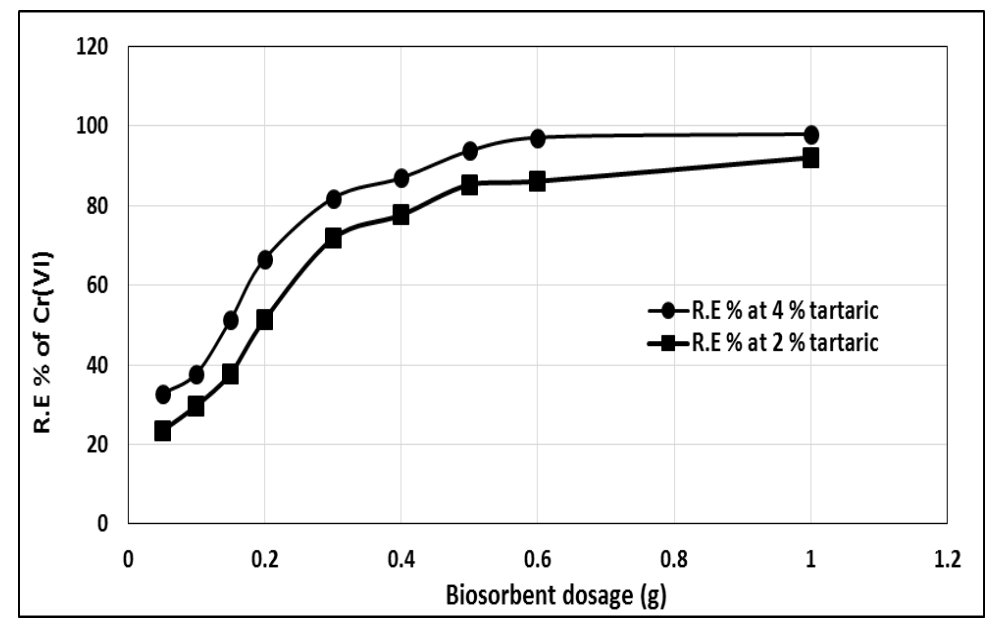

Figure 3. Effect of bio sorbent dosage on the $\mathrm{Cr}(\mathrm{VI})$ removal efficiency at initial concentration of $\mathrm{Cr}(\mathrm{VI})(80 \mathrm{ppm})$ by modified SCB with $2 \%$ or $4 \%$ tartaric acid.

\subsubsection{Effect of contact time on the biosorption of $\mathrm{Cr}$ (VI)}

The results obtained of the effect of contact time on the bio sorption of the $\mathrm{Cr}(\mathrm{VI})$ by SCB modified with $2 \%$ or $4 \%$ tartaric acid at $25^{\circ} \mathrm{C}$ were shown in Figure 4.Chromium(VI) solution (20 $\mathrm{mL})$ of initial concentrations $(20,50$ and $80 \mathrm{ppm})$ at $\mathrm{pH} 1.5$ were added to $0.2 \mathrm{~g}$ of the biosorbent in a $250 \mathrm{ml}$-flat bottom bottle at 
$25^{\circ} \mathrm{C}$ and the mixture was stirred on a shaker at $300 \mathrm{rpm}$ with different contact times. The mechanism of the adsorption of $\mathrm{Cr}(\mathrm{VI})$ was tested using pseudo first-order and pseudo second-order kinetic models. ${ }^{23-24}$ It was observed that the increase in the contact time increase the amount of metal ions adsorbed up to 40 minutes. The rapid removal at the initial contact time may be attributed to long time of contact and availability of active sites, after the equilibrium is reached at 40 minutes. The adsorption dynamics was affected by initial metal ion concentration.
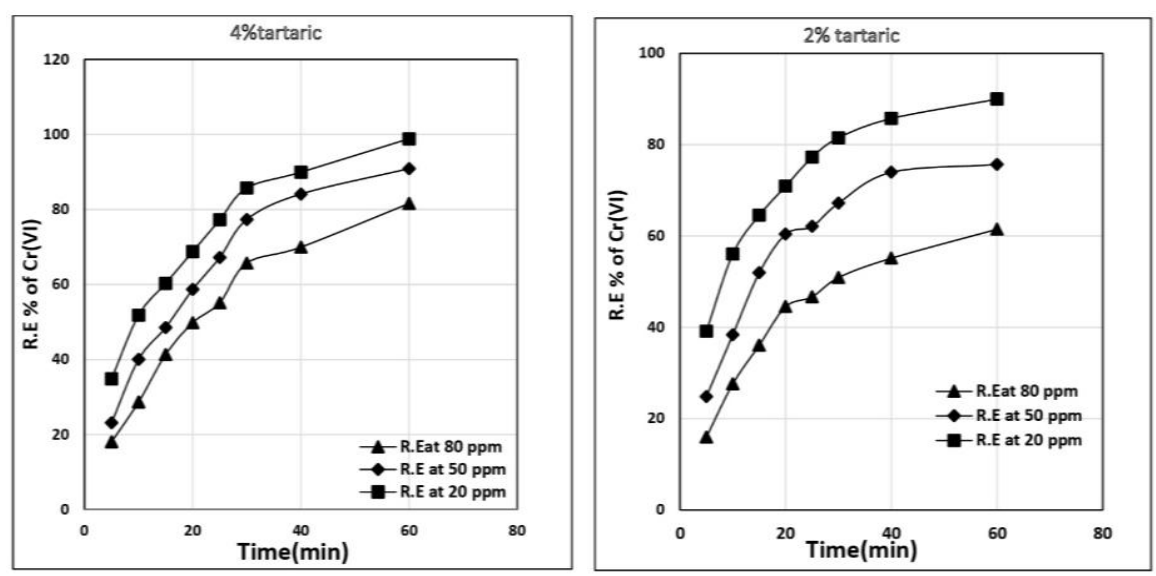

Figure 4. Effect of contact time on $\operatorname{Cr}(V I)$ removal efficiency at different initial concentrations $(20,50$ and $80 \mathrm{ppm})$ by modified SCB with $2 \%$ or $4 \%$ tartaric acid.

\subsubsection{Effect of temperature on the bio sorption of $\operatorname{Cr}(\mathrm{VI})$ by modified SCB}

Effect of temperature on the bio sorption of the $\mathrm{Cr}(\mathrm{VI})$ ions was done at different temperatures $\left(25,35,40,50\right.$ and $\left.60{ }^{\circ} \mathrm{C}\right) .20$ $\mathrm{mL}$ of $\mathrm{Cr}(\mathrm{VI})$ solution of initial concentrations (50, 80and $100 \mathrm{ppm})$ at $\mathrm{pH} 1.5$ were added to $0.2 \mathrm{~g}$ of the modified $\mathrm{SCB}$ at $25^{\circ} \mathrm{C}$ and the mixture was stirred at $300 \mathrm{rpm}$ for $15 \mathrm{~min}$. The mixture was centrifuged after each experiment then the $\mathrm{Cr}(\mathrm{VI})$ concentration of the filtrate was determined using UV spectrophotometer. It is confirmed that adsorption of chromium (VI) increases with increasing of temperature for all concentrations. Further, low initial concentrations of the solution showed improved percentage of 
adsorption in comparison with higher concentration solutions. It was noted that the $\mathrm{Cr}(\mathrm{VI})$ removal efficiency and $q_{\mathrm{e}}$ at different initial concentrations $(50,80,100 \mathrm{ppm})$ by modified SCB increases as temperature increases until around $40{ }^{\circ} \mathrm{C}$, as shown in Figure 5. Because of the presence of the active site as the temperature increases the adsorption capacity will increase. This means that the rising of the temperature encourages the biosorption. Increase in binding could be due to increase in surface activity and increased kinetic energy of the chromium (VI) metal ions.
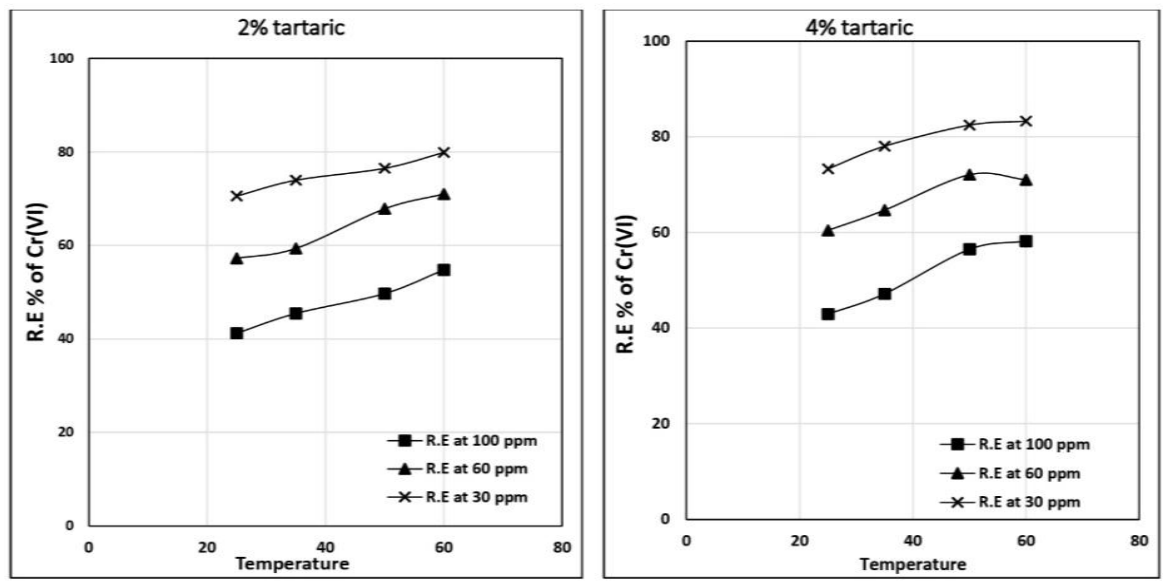

Figure 5. Effect of temperature on $\operatorname{Cr}(\mathrm{VI})$ removal efficiency at different initial concentrations $(50,80$ and $100 \mathrm{ppm})$ by modified SCB with $2 \%$ or $4 \%$ tartaric acid.

\subsubsection{Adsorption isotherm of $\mathrm{Cr}(\mathrm{VI})$ onto bio sorbents}

The distribution of $\mathrm{Cr}(\mathrm{VI})$ between the liquid and the solid phases was described by Langmuir and Freundlich isotherm model. The parameters obtained from the different isotherms provide important information about the adsorption mechanisms and surface properties $^{25}$. Langmuir and Freundlich isotherms and its parameters of $\mathrm{Cr}(\mathrm{VI})$ bio sorption onto modified SCB were shown in Figure 6. and Tables $(3 \& 4)$. The value of Freundlich exponent $n$ indicates better bio sorption mechanism and formation of relatively stronger bond between adsorb ate and bio sorbent as $n$ values wear greater than 1.0 and $1 / n$ values were between 0.0 and 1 which means that the $\mathrm{Cr}(\mathrm{VI})$ bio sorption onto modified SCB are favourable under the 
studied conditions. Freundlich model has a better fitting model according to linearity coefficient $R^{2}$.
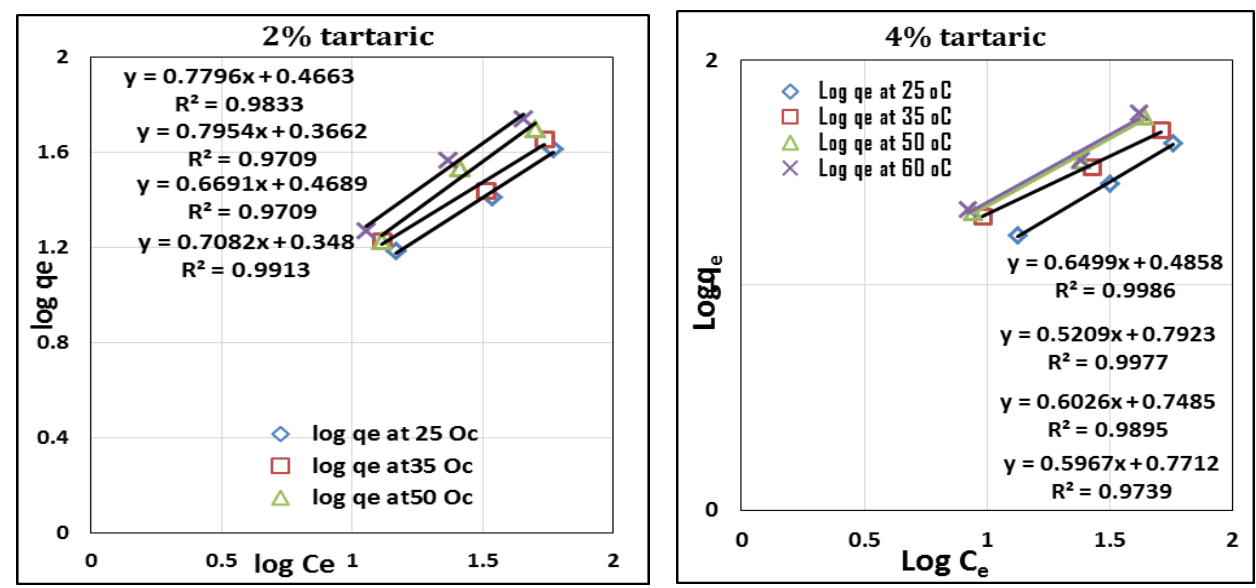

Figure 6. Linearized bio sorption isotherms of Freundlich

Table 3. Isotherm constants of $\mathrm{Cr}(\mathrm{VI})$ bio sorption onto SCB 2 $\%$ tartaric acid.

\begin{tabular}{|c|c|c|c|}
\hline \multirow{2}{*}{ Temp. ${ }^{0} \mathrm{~K}$} & \multicolumn{3}{|c|}{ Freundlich } \\
\cline { 2 - 4 } & $n$ & $K_{\mathrm{f}}$ & $\boldsymbol{R}^{\mathbf{2}}$ \\
\hline 298 & 1.28 & 2.93 & $\mathbf{0 . 9 8 3 3}$ \\
\hline 308 & 1.26 & 2.32 & 0.9709 \\
\hline 323 & 1.49 & 2.94 & 0.9709 \\
\hline 333 & 1.41 & 2.23 & 0.9913 \\
\hline
\end{tabular}

Table 3. Isotherm constants of $\mathrm{Cr}(\mathrm{VI})$ bio sorption onto SCB 4 $\%$ tartaric acid

\begin{tabular}{|c|c|c|c|}
\hline \multirow{2}{*}{ Temp. ${ }^{0} \mathrm{~K}$} & \multicolumn{3}{|c|}{ Freundlich } \\
\cline { 2 - 4 } & $n$ & $\boldsymbol{K}_{\mathrm{f}}$ & $\boldsymbol{R}^{\mathbf{2}}$ \\
\hline 298 & 1.54 & 3.06 & 0.9986 \\
\hline 308 & 1.92 & 6.2 & 0.9977 \\
\hline 323 & 1.66 & 5.6 & 0.9895 \\
\hline 333 & 68 & 5.9 & 0.9739 \\
\hline
\end{tabular}


The results show that the values of $R_{\mathrm{L}}$ ranged between 0 and 1 , thus indicating a favourable metal ions bio sorption onto modified SCB.

\subsubsection{Kinetic studies on the bio sorption of the $\operatorname{Cr}(\mathrm{VI})$ ions on SCB .}

The mechanism of the adsorption of $\mathrm{Cr}(\mathrm{VI})$ was tested using pseudo first order and pseudo second order kinetic models (equations 6 and 7)

$$
\begin{aligned}
& \ln \left(\mathrm{q}_{\mathrm{e}}-\mathrm{q}_{\mathrm{t}}\right)=\ln \mathrm{q}_{\mathrm{e}}-\mathrm{k}_{1} \mathrm{t} \\
& \left(\mathrm{t} / \mathrm{q}_{\mathrm{t}}\right)=1 /\left(\mathrm{k}_{2} \mathrm{q}_{\mathrm{e}}^{2}\right)+\left(\mathrm{t} / \mathrm{q}_{\mathrm{e}}\right)
\end{aligned}
$$

Where, $\mathrm{k}_{1}$ is the rate constant of pseudo first-order, $\mathrm{q}_{\mathrm{t}}$ is the $\mathrm{Cr}(\mathrm{VI})$ ions solution uptake in $\mathrm{mg} / \mathrm{g}$ at time $\mathrm{t}$ and $\mathrm{q}_{\mathrm{e}}$ is the $\mathrm{Cr}(\mathrm{VI})$ ions solution uptake in $\mathrm{mg} / \mathrm{g}$ at equilibrium. A plot of $\ln \left(\mathrm{q}_{\mathrm{e}}-\mathrm{q}_{\mathrm{t}}\right)$ against $\mathrm{t}$ was made and $\mathrm{q}_{\mathrm{e}}$ and $\mathrm{k}_{1}$ values were obtained from the slope and intercept, respectively. $\mathrm{k}_{2}$ is the rate constant of pseudosecond order. Plot of $\left(\mathrm{t} / \mathrm{q}_{\mathrm{t}}\right)$ against $\mathrm{t}$ gives $\left(1 / \mathrm{k}_{2} \mathrm{q}_{\mathrm{e}}{ }^{2}\right)$ as intercept from which $\mathrm{k}_{2}$ can be obtained and $\left(1 / \mathrm{q}_{\mathrm{e}}\right)$ as slope. Both models are tested for suitability using correlation coefficient, $\mathrm{R}^{2}$.It was found, the pseudo- second order model is the best fitting model according to linearity coefficients $R^{2}$ and the experimental $q_{\mathrm{e}}$ was closed to the calculated $q_{\mathrm{e}}$ for $2 \%$ or $4 \%$ tartaric acid respectively, as shown in Figure7. and Table 6.
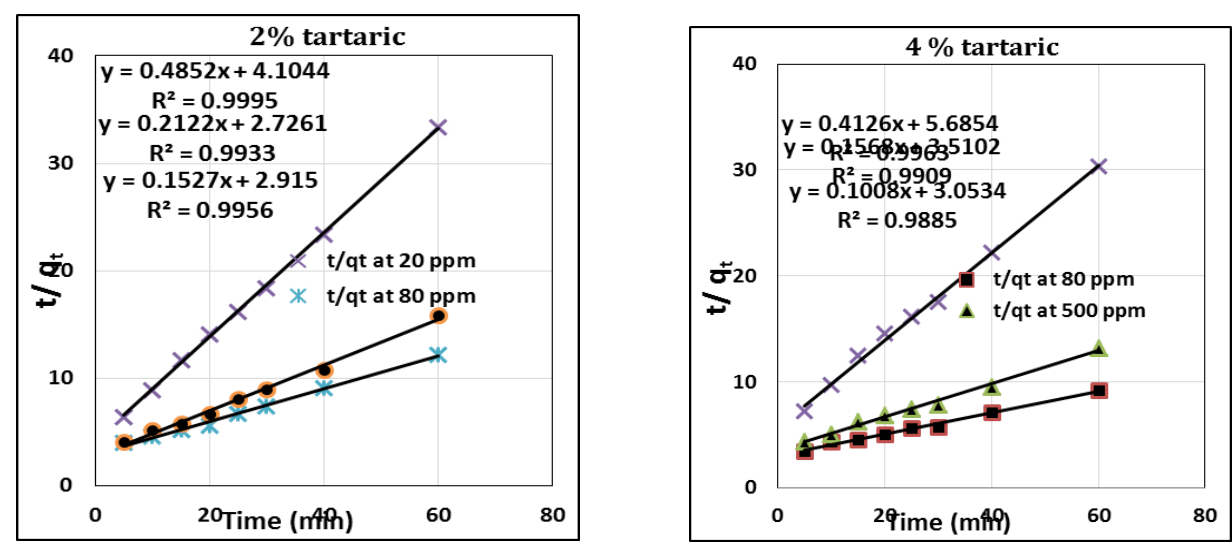

Figure 7. pseudo- second order for bio sorption of $\mathrm{Cr}(\mathrm{VI})$ by $2 \%$ or 4\% tartaric acid modified SCB 
Table 6. Kinetic parameters of $\mathrm{Cr}(\mathrm{VI})$ biosorption onto modified SCB with $2 \%$ or $4 \%$ tararic acid.

\begin{tabular}{|c|c|c|c|c|c|c|c|}
\hline \multirow[b]{2}{*}{ Concentration } & \multicolumn{3}{|c|}{$\begin{array}{c}\text { Pseudo- second order } \\
\mathbf{2 \%} \text { tartaric acid }\end{array}$} & \multicolumn{3}{|c|}{$\begin{array}{l}\text { Pseudo- second order } \\
2 \%, 4 \% \text { tararic acid. }\end{array}$} & \multirow[b]{2}{*}{$\begin{array}{l}\text { Observed } \\
\mathrm{q}_{\mathrm{e}} \mathrm{mg} \mathrm{g}^{-1}\end{array}$} \\
\hline & $\begin{array}{c}\mathrm{K}_{2}(\mathrm{~g} \\
\mathrm{mg}^{-} \\
\left.{ }^{1} . \mathrm{min}^{-1}\right)\end{array}$ & $\begin{array}{c}\mathbf{q}_{\mathrm{e}} \\
\left(\mathrm{mg} \mathrm{g}^{-1}\right)\end{array}$ & $\mathbf{R}^{2}$ & $\begin{array}{c}\mathrm{K}_{2}(\mathrm{~g} \\
\mathrm{mg}^{-} \\
\left.{ }^{1} . \mathrm{min}^{-1}\right)\end{array}$ & $\underset{\left(\mathbf{m g} \mathbf{g}^{-}\right.}{\mathbf{q}_{\mathbf{1}}}$ & $\mathbf{R}^{2}$ & \\
\hline At $C_{0} 20$ ppm & 0.06 & 2.1 & 0.9995 & 0.03 & 2.4 & 0.9963 & $2.15,2.5$ \\
\hline At $C_{0} 50$ ppm & 0.02 & 4.7 & 0.9933, & 0.01 & 6.3 & 0.9909 & $4.3,6.1$ \\
\hline At $C_{0} 80 p p m$ & 0.01 & 6.5 & 0.9956 & 0.0033 & 9.9 & 0.9885 & $6.2,9.7$ \\
\hline
\end{tabular}

\section{Conclusion}

Removal of poisonous $\mathrm{Cr}(\mathrm{VI})$ from solutions using selected adsorbents modified SCB was the most effective for the removal reached more than $97 \%$ for $\mathrm{Cr}(\mathrm{VI})$ at concentration of $80 \mathrm{ppm}$ at $\mathrm{pH}$ 1.5. Increase in the dose of adsorbent, initial concentration of $\mathrm{Cr}(\mathrm{VI})$ and increase in contact time up to 40 minutes are favourable for all increase the adsorption of $\mathrm{Cr}(\mathrm{VI})$. The kinetic of the $\mathrm{Cr}(\mathrm{VI})$ adsorption on SCB was found to follow pseudo - second order mechanism. The adsorption data can be satisfactorily explained by Freundlich isotherm. Higher sorption capacity of this sorbent indicates that SCB can be used for the treatment of chromium effluent.

\section{References}

1. Bailey, S. E; Olin, T. J; Bricka, R. M. and Adriana, D. D. (1999). A review of potentially low-cost sorbents for heavy metals, J. Water Research, 33, 2469-2479.

2. Dorris, K. L; Zhang, Y; Shukla, A. and Shukla, S. S. (2000). The removal of heavy metal from aqueous solutions by sawdust adsorption removal of copper, J. Hazard Mater., B80,33-42

3. Al-Asheh, S; Banat, F; Al-Omari, R. and Duvnjak, Z. (2000). Predictions of binary sorption isotherms for the sorption of heavy metals by pine bark using single isotherm data, Chemosphere, 41, 659- 665. 
4. Dakiky, M; Khamis, M; Manassra, A. and Mer'eb, M. (2002). Selective adsorption of chromium (VI) in industrial wastewater using lowcost abundantly available adsorbents. Adv. Environ. J., 6, 533- 540 .

5. Kumar, U. and Bandyopadhyay, M. (2006) Sorption of cadmium from aqueous solution using pretreated rice husk, Bioresour. Technol., 97, 104-109.

6. Erdem, E; Karapinar, N. and Donat, R. (2004). The removal of heavy metal cations by natural zeolites, J. Colloid Interface Sci.,280, 309-314.

7. Lee, B. G. and Rowell, R. M. (2004). Removal of Heavy Metal Ions from Aqueous Solutions Using Lignocellulosic Fibers, $j$. of Natural Fibers, Vol. 1(1), 97-108.

8. Liu, C; Hao Ngo, H. and Guo, W.(2015). Equilibrium and kinetic studies of various heavy metals on sugarcane Bagasse, $j$. of Water Sustainability, 5(2) 59-73,

9. Joseph, O; Rouez, M; Métivier-Pignon, H; Bayard, R; Emmanuel, E. and Gourdon, R. (2009). Adsorption of heavy metals on to sugar cane bagasse: Improvement of adsorption capacities dueto anaerobic degradation of the biosorbent, Environ. Technol., 30(13), 1371-1379.

10. Kumar, A. and Sahu, O. (2013). Sugar Industry Waste as Removal of Toxic Metals from Waste Water, World J. Chem. Educ., 1(1), 17-20.

11. Caraschi, J. C; Campana, F. S. P. and Curvelo, A. A. S. (1996) Carboximetilação de polpas de bagaço de cana de açúcar e caracterização dos materiaisabsorventesobtidos Polímeros. Cien. Tecnol.,3, 24.

12. Xiao, B; Sun, X. F. and Sun, R. C. (2001). The Chemical Modification of Lignins with Succinic Anhydride in Aqueous Systems, Polym. Degrad. Stability, 71, 223-231.

13. Kowalski, Z. (1994). Treatment of chromic tannery wastes. $J$. Hazard. Mater., 37, 137-141. 
14. Cieslak-Golonka, M. (1996). Toxic and mutagenic effects of chromium(VI). Polyhedron, 15(21), 3667-3689.

15. Dahbi, S; Azzi, M. and de la Guardia, M. (1999). Removal of hexavalent chromium from wastewaters by bone charcoal, Fresenius J. Anal. Chem., 363, 404-407.

16. Orhan, Y. and Buyukgangor, H. (1993). The removal of heavy metals by using agricultural wastes. Water Sci. Technol., 28, 247255.

17. Kemmer, N. F. (1988). Precipitation, Nalco Water Handbook, Publisher McGraw Hill, 10.18-10.20, (Chapter 10).

18. Volesky, B. and Holan, Z. R. ((1995). Biosorption of Heavy Metals. Biotechnol. Prog., 11, 235-250.

19. Khan, N. A. and Ali, S. I. (2001). Ayub, S., Effect of pH on the Removal of Chromium (Cr) (VI) by Sugarcane Baggase. Sci. Tech., 6, 13-19.

20. Langmuir, I. (1916). The constitution and fundamental properties of solids and liquids I. Solids, J. Am. Chem. Soc., 38(11), 2221-2295

21. Freundlich, H. M. F. (1906). Uber die Adsorption in Losungen, Z. Phys. Chem., 57, 385-470

22. Hall, K.R; Eagleton, L. and Vermeulen, T. (1996). Pore and solid diffusion kinetics infixed bed adsorption under constant pattern conditions, Ind. Eng. Chem. Fundam.5, 221-223.

23. Corbett, J. F. (1972). Pseudo first-order kinetics, J. Chem. Educ., 49 (10), p 663,

24. Ho, Y. S. and McKay, G.(1972). Pseudo-second order model for sorption processes, Process Biochem., 34(5), 451-465.

25. Abd El-Aziz, A. S.; Aly, A. A. M.; Abd El Wahab, M. M.; Soliman, S.A.; Abd El-Hafez, A. A.; Helmey, V.; Goda, M.N. (2013) Energy and Env. Engineering. 1, 10. 


\section{المذص العربي}

إزالة الكروم (IV) هن الحاليل المائية باستخداه هصاصة قصب

\section{السكر المعالج بمض الطرطريك.}

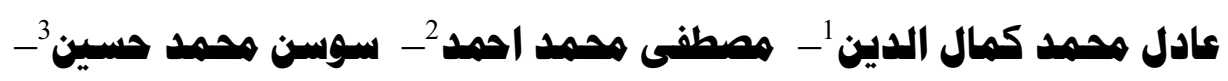
الهام ياسين هاشم 1

1 قستم الكيمياء - كلية العلوم - هامعة أسبوط - مصر.

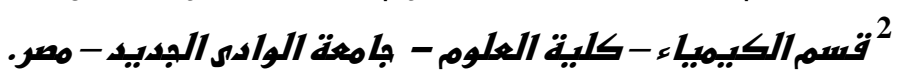

3 كلية تكنولوبيا صنا عة السكر والسنا عات التكاملية- بامعة أسيوط - مصر.

تقام هذه الاراسة استخدام بقايا بعض النباتات الطبيعية مثل مصاصة

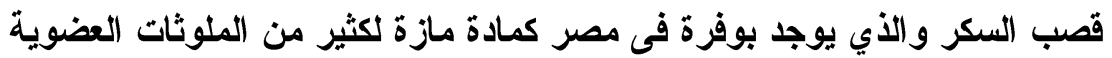

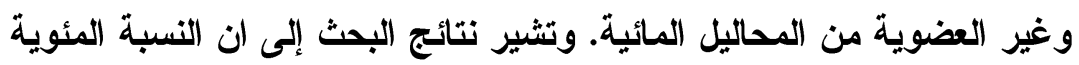

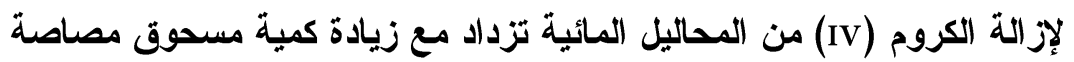

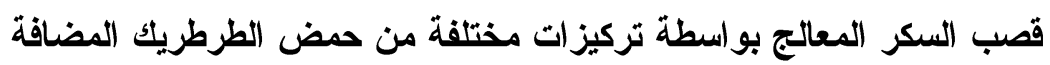

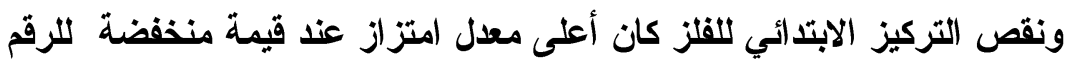

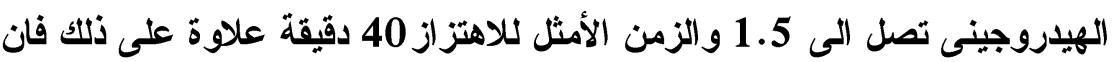

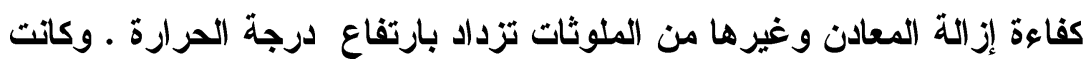

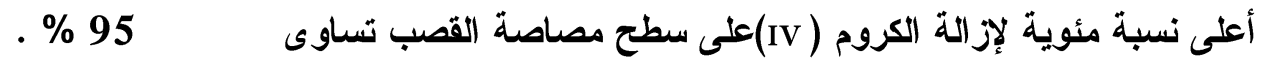

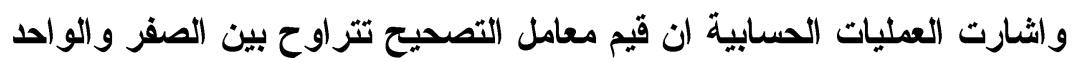

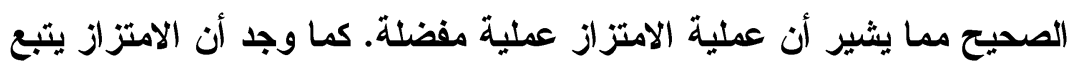

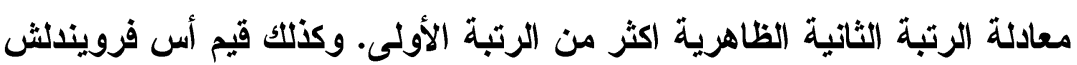

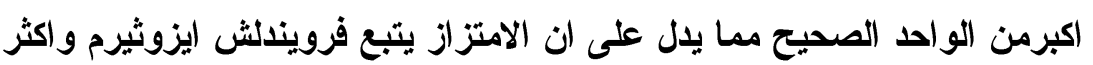

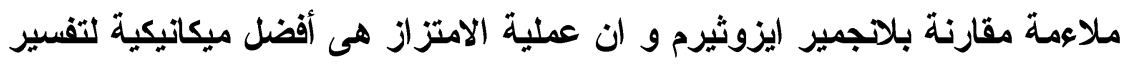

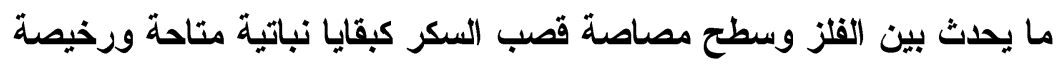

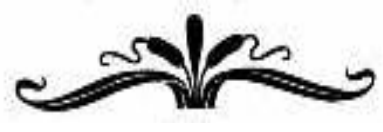
وصديقة للبيئة. 